[Contribution from the Chemical Laboratories, Columbia University, No. 329.]

\title{
THE TRANSITION OF DRY AMMONIUM CHLORIDE.
}

By Alexander Smith, Herbert Eastlack, and George Scatchard. Received August 28, 1919.

\section{Introduction and Theoretical Part.}

The object of this work was to determine whether dry ammonium chloride changes to a different crystalline form at $184.5^{\circ}$ as ordinary ammonium chloride does. The particular interest of this problem lies in its possible bearing on the anomalous vapor density of dry ammonium chloride.

It has been definitely established by the work of Breton Baker ${ }^{1}$ that the reaction

$$
\mathrm{NH}_{4} \mathrm{Cl} \rightleftharpoons \mathrm{NH}_{3}+\mathrm{HCl}
$$

does not proceed in either direction in the absence of water as catalyst. As is well known, the vapor density of undried ammonium chloride from $300^{\circ}$ to $360^{\circ}$ corresponds to a high degree of dissociation; ${ }^{2}$ but Baker found by both the Dumas and Victor Meyer methods that the vapor density of the dried substance corresponds closely to $\mathrm{NH}_{4} \mathrm{Cl}$, indicating no dissociation. Since both of these methods require about one atmosphere for operation, we may infer that the vapor pressure of the dried salt is about the same as of the undried. F. M. G. Johnson ${ }^{3}$ has measured the vapor pressure of undried and dried ammonium chloride, using the same apparatus and substance for each, and has found that the vapor pressures are the same from $212^{\circ}$ to $333^{\circ}$, but that the vapor density of the undried sample at $323^{\circ}$ (420 $\mathrm{mm}$. pressure) corresponds to $98 \%$ dissociation, while that of the dried substance at the same temperature and with equal pressure corresponds to only $8 \%$ dissociation. In his method, the vapor density bulb is at a higher temperature than the bulb containing the solid salt, and he is, therefore, not dealing with the saturated vapor.

The partial pressure of undissociated ammonium chloride vapor in equilibrium with the undried solid must then be small while that in equilibrium with the dried solid is practically the total pressure. Abegg ${ }^{4}$ was the first to call attention to this apparent anomaly of the change in the equilibrium point of a heterogeneous equilibrium by a catalyst, and it was at his suggestion that Johnson's work was undertaken. One of the most plausible explanations is that of Wegscheider ${ }^{5}$ - that the transition of ammonium chloride does not take place in the absence of water,

1 Baker, J. Chem. Soc., 65, 615 (1894); 73, 422 (1898).

$265 \%$ at $300^{\circ}$, and $63 \%$ at $330^{\circ}$ for the saturated vapor. (Smith and Lombard, Thrs Journal, 37, 48 (I915).)

'Johnson, Z. physik. Chem., 6I, 457 (I908).

4 Abegg, Ibid., 61, 455 (rgo8).

- Wegscheider, Ibid., 62, 607 (Ig08). 
and that the pressure of $\mathrm{NH}_{4} \mathrm{Cl}$ from the unstable form is accidentally the same as the total pressure of $\mathrm{NH}_{4} \mathrm{Cl}, \mathrm{NH}_{3}$ and $\mathrm{HCl}$ from the stable form.

Scheffer, ${ }^{1}$ who determined the transition point as $184.5^{\circ}$ and measured the heat of transition and the specific heats of the two forms near this temperature, does not consider the thermal effect large enough to explain the phenomenon. Lately, Wegscheider ${ }^{2}$ has calculated the heat of transition necessary, and has found that it would be 4 times the value found by Scheffer. His calculations contain many assumptions that are little justified, but the allowance for error is so large that we may agree with his conclusions. He then suggests other explanations by transition points, which will be discussed below in relation to our own work.

The transition point was determined by the ordinary thermal method, which depends upon the latent heat of transition. The simplest form of this method is to place a thermometer with its bulb in the center of a few grams of the substance in a test-tube, to place the test-tube in an efficiently stirred bath of relatively large heat capacity, also equipped with a thermometer, and to heat or cool the bath regularly and fairly rapidly, determining the readings of the two thermometers at frequent intervals.

It is customary to plot the temperature as ordinates and the times as abscissas. The curve for the bath is then a nearly straight line. When there is no change of phase in the substance, its curve is very nearly parallel to that of the bath but lies to its right; the perpendicular distance between the two lines represents the temperature gradient between the outer surface of the substance and the thermometer bulb. But near the transition point there is a distinct change in the form of the curve. The tendency of the substance is to remain at the constant temperature of the transition point until all is transformed, which would give a horizontal line at the transition point. But the phenomena of superheating or supercooling (which are conspicuous with ammonium chloride) may cause an initial passing of the transition point with a later return toward it, which is illustrated by the cooling curve (Fig. 2). Also, the rapidly changing temperature of the bath may cause a gradual change of temperature during transition. The combination of the two effects is shown by the heating curve (Fig. I), where the rapid addition of heat had straightened out the sag due to superheating, but the horizontal line is above the true transition point. In any case, the curve approaches the horizontal near the transition point, and then becomes much steeper than the curve for the bath after all the substance is transformed.

\footnotetext{
1 Scheffer, Versiag. Akad. Wetenschappen Amsterdam, I8, 446 (1915); Ibid., I8, $1498(1916)$.

${ }^{2}$ Wegscheider, Z. anorg. Chem., I03, 207 (I9I8).
} 
The quantity of substance, the method of packing, and the size of the thermometer bulb also have considerable influence on the shape of the curves. For these reasons this method generally serves only for an approximate determination of transition points. So we have used ordinary, uncalibrated mercury thermometers, and have made no correction for exposed stem.

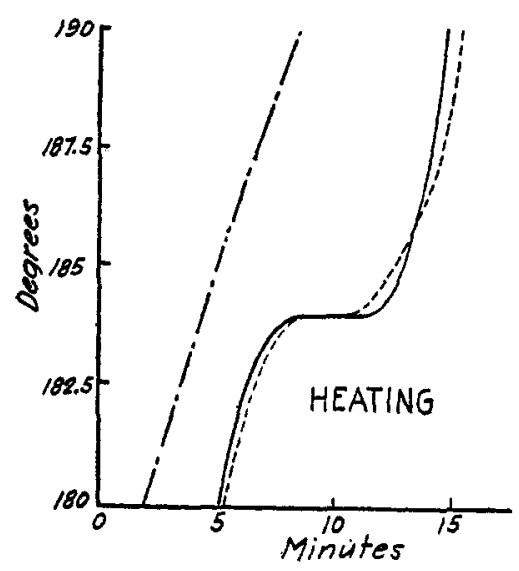

Fig'

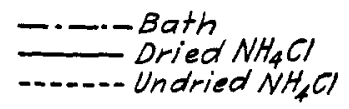

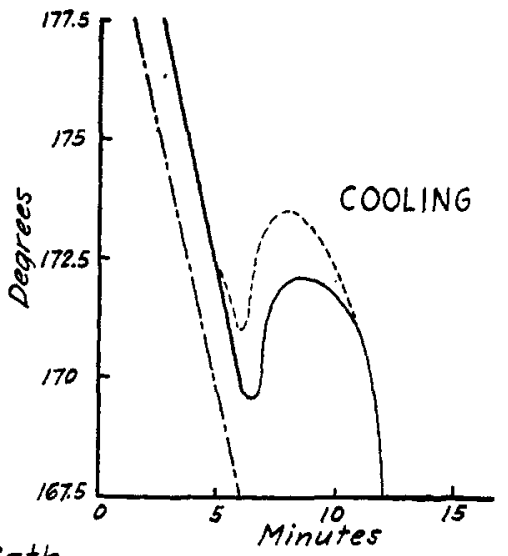

Fig 2 as.

Figs. $x$ and 2 are typical heating and cooling curves. They represent the curves for the bath (dot and dash line), for ordinary undried ammonium chloride in a test-tube (dotted line), and for dried ammonium chloride (full line), all determined at the same time. For the last it was necessary to use a more complicated apparatus to obtain and maintain anhydrous conditions. The manipulation and the corresponding table are given under Apparatus No. 4. They show very clearly a transition in the interval $172^{\circ}$ to $184^{\circ}$ (uncorr.), and show how closely the curves for the dried and the undried salt correspond. Since these determinations are only approximate, it has not been considered worth while to give the curves for the other tables, since a glance at the tables, especially the columns giving the average temperature change per minute, will show that there is an inflection in each case at about this temperature.

Let us compare the thoroughness of our drying with that of the investigators who have found abnormal densities. Baker ${ }^{1}$ dried his apparatus by heating in boiling mercury while a current of dry air was passed through. After the introduction of the substance and the phosphorus pentoxide, he let it stand not longer than two weeks at room temperature. Johnson ${ }^{1}$ performed the preliminary drying by heating the evacuated apparatus a long time at $300^{\circ}$. After the introduction 
of the materials, he allowed it to stand 5 weeks at ordinary temperature. We dried the apparatus by heating with a small flame while passing through a current of dry air, and dried the salt after its introduction, at $155^{\circ}$ to $165^{\circ}$ for 45 days, or 3 years at room temperature, with care to present as large a surface of the solid as possible. Therefore, our material was much more carefully dried than that which did not dissociate. In every case the transition occurred as with the undried ammonium chloride.

Wegscheider's first explanation by the failure of dried ammonium chloride to undergo the known transition at $184.5^{\circ}$ is rendered improbable by the work of Scheffer and wholly untenable by the fact that it does undergo transition. The fact that the transition occurs at the same temperature also excludes the explanation by another transition at a lower temperature. Our work has no bearing on a second transition at a higher temperature. But if that were to account for the anomaly, the heat of transition would have to be very large, and the fact that Scheffer searched for it in vain strongly indicates its nonexistence.

Wegscheider's third possible explanation is that ordinary $\alpha-\mathrm{NH}_{4} \mathrm{Cl}$ is a labile form, which changes to $\alpha^{\prime}-\mathrm{NH}_{4} \mathrm{Cl}$, but only at higher temperatures and in the presence of moisture. It is the transition $\alpha^{\prime}-\mathrm{NH}_{4} \mathrm{Cl}=$ $\beta-\mathrm{NH}_{4} \mathrm{Cl}$ which occurs at $184.5^{\circ}$, and the $\alpha-\mathrm{NH}_{4} \mathrm{Cl}$ does not undergo transition. This would imply a transition from $\alpha-\mathrm{NH}_{4} \mathrm{Cl}$ to $\alpha^{\prime}-\mathrm{NH}_{4} \mathrm{Cl}$, although not necessarily at a definite temperature, and it is impossible as an explanation since dried ammonium chloride does undergo transition at this higher temperature.

His fourth explanation is that the ordinary $\alpha-\mathrm{NH}_{4} \mathrm{Cl}$ is stable and undergoes transition at $I 84.5^{\circ}$ to the $\beta$-form; but that sometimes in the preparation, a labile $\alpha^{\prime}-\mathrm{NH}_{4} \mathrm{Cl}$ is formed, which does not undergo transition in the absence of moisture and which evaporates without dissociation. Evidently, one may assume any value for the heat of reaction of $\alpha^{\prime}-\mathrm{NH}_{4} \mathrm{Cl}={ }^{\prime \prime} \alpha-\mathrm{NH}_{4} \mathrm{Cl}$ and for the specific heat of the $\alpha^{\prime}-\mathrm{NH}_{4} \mathrm{Cl}$ without contradicting any experimental evidence, if he assumes that all calorimetric measurements have been made on the stable $\alpha$-form. Similarly, our results would have no bearing on the case, as we did not happen to work with the $\alpha^{\prime}-\mathrm{NH}_{4} \mathrm{Cl}$.

Wegscheider supports this hypothesis with the statement that Johnson with dried ammonium chloride obtained sometimes undissociated and sometimes dissociated vapor. However, Johnson worked with only one sample of dried ammonium chloride, upon which he made one measurement of vapor density and one ascending and descending vapor-pressure curve. He then allowed moisture to enter and made the same measurements on the undried substance. Moreover, a series of several measurements of the vapor density of ammonium chloride dried 9 months at room tem- 
perature gave not a single case of vapor density corresponding to dissociation. ${ }^{1}$ The only recorded case of ammonium chloride which had been submitted to an attempt at drying and gave dissociated vapor is that of Gutmann, ${ }^{2}$ and Baker ${ }^{3}$ claims that he failed to obtain anhydrous conditions. Therefore, there is no justification for attributing the higher vapor density to a rare, accidental form. However, the only experimental answer to this assumption would be to make simultaneous determinations of vapor density and transition point, and so see whether the same sample did undergo transition and give undissociated vapor.

\section{Experimental Part. \\ Material.}

Ammonium Chloride.-For Tubes 2 and 3, "Baker's Special" ammonium chloride was boiled with dil. nitric acid, recrystallized twice from distilled water, sublimed in vacuo, recrystallized, resublimed, recrystallized, powdered finely, and dried at $110^{\circ}$ for 24 hours. For Tubes 4,5 and 6 , c. P. ammonium chloride was recrystallized from distilled water, dried, sublimed in vacuo, ground to a fine powder, and dried at $112^{\circ}$ for several hours.

Phosphorus Pentoxide. - Phosphorus pentoxide was sublimed in a current of oxygen over red-hot platinum sponge. It was free from phosphorus trioxide.

\section{Apparatus.}

The apparatus, as shown in Fig. 3, consists of a tube $E$ to contain the ammonium chloride and the thermometer bulb and with a long neck for the stem of the thermometer and a side tube with two bulbs ( 1 and 2) for phosphorus pentoxide, which was also used to make the connection to the pump at $\mathrm{C}$. The thermometers were the ordinary $360^{\circ}$ type selected to fit tightly in the neck of the tube.

\section{Preparation of Apparatus.}

The apparatus was thoroughly cleaned with sulfuric acid-dichromate mixture and with distilled water, and was finally dried by heating over its entire surface with a small Bunsen flame while drawing through

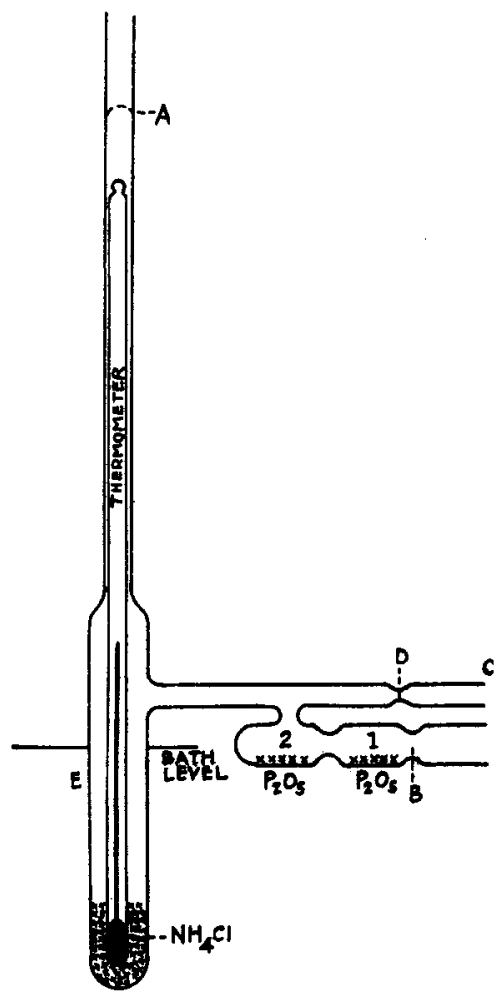

${ }^{1}$ Unpublished work of Smith and Lombard. Fig. 3.-Apparatus for the observation

2 Gutmann, $A$ nn., 299, 267 (1898).

3 Baker, J. Chem. Soc., 73, 422 (1898). of transition of "dry" ammonium chloride. 
a current of dry air. While the tube was still hot, about $15 \mathrm{~g}$. of ammonium chloride was quickly introduced directly from the oven, the carefully cleaned and dried thermometer was put into place, and the tube was sealed off at $\mathrm{A}$. Then 2 or $3 \mathrm{~g}$. of phosphorus pentoxide was put into bulb $I$ and the constriction at $B$ sealed off.

\section{Drying and Determination of Transition Point.}

Apparatus No. 2.- The apparatus was sealed to the mercury pump at $\mathrm{C}$, exhausted to $0.00 \mathrm{Im}$. pressure (McLeod gage), and sealed off at D. The bulb $\mathrm{E}$, containing the ammonium chloride, was heated by boiling anisole $\left(154^{\circ}\right)$ while the phosphorus pentoxide bulbs were cooled by immersion in running tap water. After 3 days' heating, about $1 / 3$ of the pentoxide was carefully distilled from bulb I to bulb 2 .

After nine days' continuous heating, heating and cooling curves were made. The heating was done in a bath of "crisco," in which the Tube $\mathrm{E}$ was immersed well above the level of the ammonium chloride. The bath was made of a liter beaker wrapped with asbestos and heated by an electric hot-plate in a room with windows and doors closed to prevent drafts. In each case the temperature of the bath, as determined at frequent intervals, increased regularly but with diminishing rapidity at the higher temperatures.

As indicated in the following table, the transition occurred at $183^{\circ}$ and at $\mathrm{I} 75^{\circ}$ on heating and cooling, respectively:

$\begin{array}{rccccc}\begin{array}{r}\text { Temp. } \\ \text { Degrees. }\end{array} & \begin{array}{c}\text { Heating rate } \\ \text { Degrees. }\end{array} & \begin{array}{c}\text { Time. } \\ \text { Minutes. }\end{array} & \begin{array}{c}\text { Temp. } \\ \text { Degrees. }\end{array} & \begin{array}{c}\text { Cooling rate. } \\ \text { Degrees. }\end{array} & \begin{array}{c}\text { Time. } \\ \text { Minutes. }\end{array} \\ 175.0 & \ldots .0 & 0.0 & \text { I77.0 } & \ldots \ldots & \mathbf{0 . 0} \\ 180.0 & +1.7 & 3.0 & 175.0 & -1.3 & 1.5 \\ 183.0 & 0.9 & 6.3 & 174.1 & 0.5 & 3.25 \\ 183.2 & 0.1 & 8.0 & 174.5 & +0.2 & 5.0 \\ 183.5 & 0.2 & 9.5 & 174.7 & +0.2 & 6.0 \\ 184.0 & 0.3 & 11.0 & 174.0 & -0.2 & 9.0 \\ 185.0 & 0.4 & 13.5 & 173.0 & 0.4 & 11.6 \\ 190.0 & 1.2 & 17.6 & 170.0 & 0.9 & 15.0\end{array}$

- Rate is average change in degrees per minute since previous reading.

The bulb was further heated at $I 55^{-1} 65^{\circ}$ in an electrically heated air bath. After 45 days' continuous heating, the transition point was redetermined. Just as the slight drop in temperature from $184^{\circ}$ was observed, the tube cracked-presumably due to the expansion of the salt on transition, for during the heating it had become packed in a hard mass between the thermometer and the tube. The determination had proceeded far enough to indicate a transition of $184^{\circ}$.

$\begin{array}{ccc}\begin{array}{c}\text { Temp. } \\ \text { Degrees. }\end{array} & \begin{array}{c}\text { Rate. } \\ \text { Degrees. }\end{array} \\ \text { I75.0 } & \ldots . & \text { Time. } \\ \text { I80.0 } & +1.2 & 0.0 \\ \text { I82.0 } & \text { I.O } & 4.3 \\ \text { I84.0 } & 1.0 & 6.3 \\ \text { I83.8 } & -0.2 & 8.4\end{array}$


Tubes $3,4,5$ and 6 were sealed to the pump at C, exhausted to $0.00 \mathrm{r}$ mm., and allowed to stand overnight; they were then heated with a small flame (with the exception of the ammonium chloride and the pentoxide bulbs), again exhausted to $0.001 \mathrm{~mm}$., and sealed off at D. They were similarly heated several times during the next few days. Finally, the pentoxide was carefully distilled into bulb 2 .

The ammonium chloride was shaken down so that, with the apparatus on its side, a large surface of the salt over nearly the full length of Tube E was exposed to the drying atmosphere, and the tubes were left thus to dry.

Apparatus No. 6.-After drying 14 months (June I, I9I6 to August I0, I9I7), the transition point was determined as before. During the determination, the pentoxide bulbs were cooled in ice-water. The transition occurs regularly at $184-185^{\circ}$. The table includes the temperature of the bath.

\begin{tabular}{|c|c|c|c|c|}
\hline $\begin{array}{l}\text { Temp. of } \\
\text { NHAcl. } \\
\text { Degrees. }\end{array}$ & $\begin{array}{l}\text { Rate. } \\
\text { De-- } \\
\text { grees. }\end{array}$ & $\begin{array}{l}\text { Temp. } \\
\text { of bath. } \\
\text { Degrees. }\end{array}$ & $\begin{array}{c}\text { Rate. } \\
\text { De- } \\
\text { grees. }\end{array}$ & $\begin{array}{c}\text { Time. } \\
\text { Minutes }\end{array}$ \\
\hline 175.0 & $\ldots$ & 183 & $\ldots$ & 0.0 \\
\hline I 80.0 & +3.3 & $\ldots$ & $\ldots$ & I. 5 \\
\hline 182.0 & 3.0 & $\ldots$ & $\ldots$ & 2.2 \\
\hline 183.0 & 2.5 & $\ldots$ & $\ldots$ & 2.6 \\
\hline 184.0 & I .I & $\therefore$ & $\ldots$ & 3.5 \\
\hline 184.5 & 0.5 & $\ldots$ & $\ldots$ & 4.6 \\
\hline 185.0 & 0.7 & $\ldots$ & $\ldots$ & $5 \cdot 3$ \\
\hline 186.0 & 0.8 & $\ldots$ & $\ldots$ & 6.6 \\
\hline 190.0 & 1.9 & $\ldots$ & $\ldots$ & 8.7 \\
\hline 193.0 & 1. 8 & 202 & I 8 & I0. 4 \\
\hline 194.0 & 0.5 & $\ldots$ & $\ldots$ & I2. 3 \\
\hline 193.0 & -0.5 & $\ldots$ & $\ldots$ & I 4.3 \\
\hline 192.0 & -1.0 & 2 I I & 1.8 & I 5.3 \\
\hline I9I .O & -0.9 & $\ldots$ & $\ldots$ & 16.4 \\
\hline 190.0 & -0.7 & $\ldots$ & $\ldots$ & 17.9 \\
\hline
\end{tabular}

\begin{tabular}{|c|c|c|c|c|}
\hline $\begin{array}{l}\text { Temp. of } \\
\text { NHicl. } \\
\text { Degrees. }\end{array}$ & $\begin{array}{l}\text { Rate. } \\
\text { De- } \\
\text { grees. }\end{array}$ & $\begin{array}{l}\text { Temp. } \\
\text { of bath. } \\
\text { Degrees. }\end{array}$ & $\begin{array}{c}\text { Rate. } \\
\text { De- } \\
\text { grees. }\end{array}$ & $\begin{array}{c}\text { Time. } \\
\text { Minutes. }\end{array}$ \\
\hline 189.5 & -0.2 & 219 & +1.7 & 20.1 \\
\hline 189.0 & -0.3 & $\cdots$ & $\ldots$ & 22.9 \\
\hline 189.5 & +0.2 & $\ldots$ & $\ldots$ & 25.3 \\
\hline 190.0 & 0.2 & $\ldots$ & $\ldots$ & 27.5 \\
\hline 191.0 & 0.2 & $\ldots$ & $\ldots$ & 33.8 \\
\hline 192.0 & 0.2 & $\ldots$ & $\ldots$ & 38.3 \\
\hline I93.0 & 0.4 & $\ldots$ & $\ldots$ & 40.6 \\
\hline 194.0 & 0.5 & $\cdots$ & $\cdots$ & 42.5 \\
\hline I95.0 & I. 0 & $\ldots$ & $\ldots$ & $43 \cdot 3$ \\
\hline 200.0 & 1.2 & $\ldots$ & $\ldots$ & 47.4 \\
\hline 205.0 & 2.5 & $\ldots$ & $\ldots$ & 49.4 \\
\hline 215.0 & 4.0 & 260 & 1.3 & 51.9 \\
\hline 240.0 & 0.5 & $\ldots$ & .. & 100.8 \\
\hline . & $\ldots$ & $\ldots$ & $\ldots$ & . \\
\hline . & . & $\cdots$ & .. & $\ldots$ \\
\hline
\end{tabular}

It will be observed that there is a second drop in the temperature at $194^{\circ}$. This is undoubtedly due to distillation of the ammonium chloride and a consequent isolation of the thermometer bulb. At the end of the determination, the salt had entirely distilled into the upper part of the apparatis: The same effect was observed in very carefully evacuated tubes containing ammonium chloride without the addition of phosphorus pentoxide. In 3 cases the distillation occurred at I5O, I6o and $167^{\circ}$. This larger thermal effect would of course hide a transition point. The last of these determinations is given in the following table: 


\begin{tabular}{|c|c|c|c|c|}
\hline $\begin{array}{l}\text { Temp of } \\
\text { NHici. } \\
\text { Degrees. }\end{array}$ & $\begin{array}{c}\text { Rate: } \\
\text { Degrees. }\end{array}$ & $\begin{array}{l}\text { Teunp. } \\
\text { of bath. } \\
\text { Degrees. }\end{array}$ & $\begin{array}{c}\text { Rate. } \\
\text { Degrees. }\end{array}$ & $\begin{array}{c}\text { Time. } \\
\text { Minutes. }\end{array}$ \\
\hline 160.0 & . & I 70 & & 0.0 \\
\hline I 65.0 & $+\mathrm{I} \cdot \mathrm{r}$ & I 81 & +2.3 & 4.7 \\
\hline 167.0 & 0.5 & $\ldots$ & $\ldots$ & 9.0 \\
\hline 166.8 & -0.05 & 190 & $+I . I$ & I 3.2 \\
\hline I 66.5 & $\longrightarrow 0.2$ & $\cdots$ & $\cdots$ & 14.5 \\
\hline 166.2 & -0.15 & & $\cdots$ & 16.5 \\
\hline I 66.0 & -0.4 & . & $\ldots$ & 17.0 \\
\hline$x 65.8$ & $\longrightarrow 0.07$ & $\ldots$ & $\ldots$ & 19.7 \\
\hline
\end{tabular}

\begin{tabular}{|c|c|c|c|c|}
\hline $\begin{array}{l}\text { Temp, of } \\
\text { Negrcl. } \\
\text { Degrees. }\end{array}$ & $\begin{array}{c}\text { Rate. } \\
\text { Degrees. }\end{array}$ & $\begin{array}{l}\text { Temp. } \\
\text { of bath. } \\
\text { Degrees. }\end{array}$ & $\begin{array}{c}\text { Rate. } \\
\text { Degrees. }\end{array}$ & $\begin{array}{l}\text { Tine. } \\
\text { Minutes }\end{array}$ \\
\hline I65.9 & +0.01 & 200 & to.7 & 28.2 \\
\hline I 66.0 & 0.04 & $\ldots$ & $\ldots$ & 30.5 \\
\hline 166.4 & 0.06 & $\ldots$ & $\ldots$ & 37.2 \\
\hline$\times 67.0$ & 0.1 & 210 & 0.7 & $43 \cdot 5$ \\
\hline 168.0 & $0 . \mathrm{I}$ & $\ldots$ & $\ldots$ & 51.5 \\
\hline 169.0 & 0.1 & $\ldots$ & $\ldots$ & 61.0 \\
\hline I 70.0 & $0 . I$ & $2 \times 7$ & 0.25 & 720 \\
\hline
\end{tabular}

Apparatus No. 5. - Treated exactly as No. 6, it shows the same therma effects-transition at $I 84-185^{\circ}$, and the distillation commencing at 198.5 instead of at $194^{\circ}$.

\begin{tabular}{|c|c|c|c|c|c|c|c|c|c|c|c|}
\hline $\begin{array}{c}\text { Temp. of } \\
\text { NH,Ci. } \\
\text { Degrees. } \\
173.0\end{array}$ & $\begin{array}{l}\text { Rate. } \\
\text { De- } \\
\text { grees. }\end{array}$ & $\begin{array}{c}\text { Time } \\
\text { Min- } \\
\text { utes. } \\
0.0\end{array}$ & $\begin{array}{l}\text { Temp. of } \\
\text { NH.Cl. } \\
\text { Degrees. } \\
185.0\end{array}$ & $\begin{array}{l}\text { Rate: } \\
\text { De- } \\
\text { grees. } \\
+1.7\end{array}$ & $\begin{array}{l}\text { Time. } \\
\text { Min- } \\
\text { utes. } \\
7.0\end{array}$ & $\begin{array}{c}\text { Temp. of } \\
\text { NHACl. } \\
\text { Degrees. } \\
198.5\end{array}$ & $\begin{array}{l}\text { Rate. } \\
\text { De- } \\
\text { grees. } \\
\pm 0.0\end{array}$ & $\begin{array}{l}\text { Time: } \\
\text { Min- } \\
\text { utes. } \\
16.0\end{array}$ & $\begin{array}{c}\text { Temp. } \\
\text { NHfic } \\
\text { Degree } \\
200\end{array}$ & e. & $\begin{array}{l}\text { Time. } \\
\text { Min- } \\
\text { utes. } \\
48.4\end{array}$ \\
\hline 177.0 & +4.0 & I.O & 187.0 & 2.2 & 7.9 & 198.0 & $\longrightarrow .2$ & 18.1 & 205 & 0.5 & 9.5 \\
\hline 180.0 & $3 \cdot 3$ & I. 9 & 190.0 & 3.7 & 8.7 & 197.0 & -0 & 20.8 & 210 & I. 6 & .6 \\
\hline 182.0 & 1. 8 & 3.0 & 195.0 & 2.9 & 10.4 & 196.6 & & $\cdots$ & 220 & $4 \cdot 3$ & 64.9 \\
\hline 182.5 & 0.5 & $4 \cdot I$ & 196.0 & I . 2 & I I . 2 & 197.0 & . & 26.7 & 230 & 5.9 & 66.6 \\
\hline 183.0 & 0.6 & 5.0 & 198.0 & 1.0 & 13. & r 98.0 & to.I & 37.8 & 256 & 3.9 & $73 \cdot 3$ \\
\hline 184,0 & 0.7 & 6.4 & 198.5 & 0.3 & I 5.0 & I 99.0 & $0 . I$ & 44.8 & & . & \\
\hline
\end{tabular}

Apparatus Nos. 3 and 4. - They were dried at room temperature for 3 years (June I, I916-May 15,1919 ), and then heated to $100^{\circ}$ for 3 periods of io hours each. At the end of the final period, the temperature at the very base rose to $200-250^{\circ}$, which caused the distillation of the salt from the bottom. However, the thermometers were still well surrounded by the caked salt. Heating and cooling curves were taken without cooling the pentoxide bulbs. Apparatus No. 3 .

Heating.

\begin{tabular}{|c|c|c|c|c|c|}
\hline $\begin{array}{l}\text { Temp } \\
\text { NHACl } \\
\text { Degrees }\end{array}$ & $\begin{array}{l}\text { of Rate. } \\
\text { i. De- } \\
\text { s. grees. }\end{array}$ & $\begin{array}{l}\text { Time } \\
\text { Min- } \\
\text { utes, }\end{array}$ & $\begin{array}{l}\text { Temp. of } \\
\text { NH, } \\
\text { Degrees. }\end{array}$ & $\begin{array}{l}\text { Rate. } \\
\text { De- } \\
\text { grees. }\end{array}$ & $\begin{array}{l}\text { Time. } \\
\text { Min- } \\
\text { utes. }\end{array}$ \\
\hline 170 & .. & 0.0 & 188 & +0.4 & 11.7 \\
\hline 174 & +2.2 & 1.8 & 189 & 0.7 & 13.2 \\
\hline 178 & 2.5 & 3.2 & 190 & 0.8 & 14.5 \\
\hline 182 & 2.2 & 5.0 & $9 \mathrm{I}$ & 2.0 & 15.0 \\
\hline 184 & 2.0 & 6.0 & 192 & I. 4 & 15.7 \\
\hline 185 & $3 \cdot 3$ & 6.3 & 193 & 3.3 & 16.0 \\
\hline I 86 & I,O & $7 \cdot 3$ & 195 & 4.0 & 16.5 \\
\hline 187 & 0.5 & 9.3 & 200 & 3.8 & 17.8 \\
\hline
\end{tabular}

Cooling.

\begin{tabular}{|c|c|c|c|c|c|}
\hline $\begin{array}{l}\text { Temp of } \\
\text { NH, } 1 \text {. } \\
\text { Degrees. }\end{array}$ & $\begin{array}{c}\text { Rate. } \\
\text { De- } \\
\text { grees. }\end{array}$ & $\begin{array}{l}\text { Time. } \\
\text { Min- } \\
\text { tites. }\end{array}$ & $\begin{array}{l}\text { Temp of } \\
\text { NHAci. } \\
\text { Degrees. }\end{array}$ & $\begin{array}{l}\text { Rate. } \\
\text { De- } \\
\text { grees. }\end{array}$ & $\begin{array}{l}\text { Time. } \\
\text { Min- } \\
\text { utes. }\end{array}$ \\
\hline 185.0 & $\ldots$ & 0.0 & 171 & -1.0 & 10.5 \\
\hline 180.0 & -2.4 & 2.1 & 170 & 0.8 & II. 7 \\
\hline I 75.0 & $2 . I$ & $4 \cdot 5$ & I 69 & .2 & 2.5 \\
\hline I 73,0 & 2.5 & & I68 & .0 & 3. \\
\hline 172.0 & I. 4 & 6.0 & 167 & 5.0 & I 3.2 \\
\hline 172.5 & +0.2 & 8.1 & 165 & 3.0 & 13.9 \\
\hline 172.0 & -0.4 & 9.5 & 160 & 4.2 & I5.I \\
\hline$\cdots$ & $\cdots$ & $\cdots$ & $\ldots$ & $\cdots$ & $\cdots$ \\
\hline
\end{tabular}

The transition occurs at $186^{\circ}$ and $172^{\circ}$ on heating and cooling, respectively. With ordinary ammonium chloride (undried), determined at the same time, the temperatures of transition were $186^{\circ}$ and $170^{\circ}$.

Apparatus No. 4. - The curves for this determination as well as for the bath temperatures and the curves for undried ammonium chloride are given in Figs. I and 2. 
Heating.

\begin{tabular}{|c|c|c|c|c|c|}
\hline $\begin{array}{l}\text { Temp. of } \\
\text { NH,Cl. } \\
\text { Degrees. }\end{array}$ & $\begin{array}{c}\text { Rate. } \\
\text { De- } \\
\text { grees. }\end{array}$ & $\begin{array}{l}\text { Time. } \\
\text { Min- } \\
\text { utes. }\end{array}$ & $\begin{array}{l}\text { Temp. of } \\
\mathrm{NH}_{4} \mathrm{Cl}_{\text {l. }} \\
\text { Degrees. }\end{array}$ & $\begin{array}{c}\text { Rate. } \\
\text { De- } \\
\text { grees. }\end{array}$ & $\begin{array}{l}\text { Time. } \\
\text { Min- } \\
\text { utes. }\end{array}$ \\
\hline 170 & $\ldots$ & 0.0 & 185 & +1.0 & 12.8 \\
\hline 174 & +2.0 & 2.0 & I 86 & I. 4 & 13.5 \\
\hline 178 & 2.0 & 4.0 & 187 & $3 \cdot 3$ & 1 3.8 \\
\hline 180 & 2.0 & 5.0 & I 88 & 2.5 & 14.2 \\
\hline 182 & 2.0 & 6.0 & 190 & $3 \cdot 3$ & 14.8 \\
\hline 183 & 2.0 & 6.5 & I 94 & $2 \cdot 5$ & I 5.8 \\
\hline 184 & I.O & $7 \cdot 5$ & 200 & $2 \cdot 7$ & 18.0 \\
\hline 184 & $\neq 0.0$ & I I 8 & & . & \\
\hline
\end{tabular}

Cooling.

\begin{tabular}{|c|c|c|c|c|c|}
\hline $\begin{array}{l}\text { Temp of } \\
\text { NHiCl. } \\
\text { Degrees. }\end{array}$ & $\begin{array}{c}\text { Rate. } \\
\text { De- } \\
\text { grees. }\end{array}$ & $\begin{array}{l}\text { Time. } \\
\text { Min- } \\
\text { utes. }\end{array}$ & $\begin{array}{l}\text { Ter } \\
\text { NI } \\
\mathrm{De}\end{array}$ & $\begin{array}{l}\text { of Rate. } \\
\text { l. De- } \\
\text { s. grees. }\end{array}$ & $\begin{array}{l}\text { Time. } \\
\text { Min- } \\
\text { utes. }\end{array}$ \\
\hline 184.0 & & 0.0 & I 7 I & +2.0 & 7. \\
\hline 180.0 & -2.7 & I $\cdot 5$ & 172 & +1.2 & .8 \\
\hline 176.0 & 2.4 & 3.2 & 172 & \pm 0.0 & .2 \\
\hline 172.0 & 2.2 & 5.0 & I 7 I & -0.6 & 10.8 \\
\hline 171.0 & $3 \cdot 3$ & 5 & I & I. 4 & II. \\
\hline 170.0 & I. 4 & 6.0 & 16 & $3 \cdot 3$ & II .8 \\
\hline I 69.5 & 2.5 & 6.2 & I 68 & 5.0 & I 2 . \\
\hline 170.0 & I. O & 6.7 & I 64 & 4.0 & I \\
\hline
\end{tabular}

Transition occurs at $184^{\circ}$ and $17^{\circ}$ on heating and cooling, respectively. With the undried ammonium chloride determined at the same time, the transition occurs at $184^{\circ}$ and $r 73^{\circ}$.

\section{Summary.}

I. Ammonium chloride in the absence of water (dried 45 days at $5_{55^{-}}$ $165^{\circ}$ or 3 years at room temperature with phosphorus pentoxide in a high vacuum) undergoes transition at $184.5^{\circ}$, the same as the undried salt.

2. In the thermal measurement of transition points in a high vacuum, confusion may result from the greater thermal effects of distillation.

3. Wegscheider's explanations of the anomalous vapor density of dried ammonium chloride by a failure to undergo transition in the absence of water are untenable in the light of these results.

NEW YORK, N. Y.

[CONTrIbution from the Michigan College of Mines.]

\section{THE DECOMPOSITION OF STANNOUS CHLORIDE BY WATER AND BY POTASSIUM HYDROXIDE SOLUTIONS.}

By C. M. Carson.

Received September 12, 1919.

Introductory.

The experiments described in this paper were undertaken for the purpose of determining the composition of the precipitates formed when stannous chloride is decomposed by water. For, although the appearance of these precipitates is well known, no information concerning them is found in the literature with the exception of that contained in brief papers by Ditte, ${ }^{1}$ published 37 years ago. Ditte states that $\mathrm{SnCl}_{2}$.$2 \mathrm{H}_{2} \mathrm{O}$, when boiled with water, forms a hydrated oxychloride $\mathrm{SnCl}_{2} . \mathrm{SnO}$.$6 \mathrm{H}_{2} \mathrm{O}$; that this, when boiled with water to which stannous chloride is added, little by little, forms a crystalline basic salt, ${ }_{2} \mathrm{SnCl}_{2} \cdot 3 \mathrm{SnO} .6 \mathrm{H}_{2} \mathrm{O}$; and that the last named by further treatment with stannous chloride solution, yields a less basic precipitate, $\mathrm{SnCl}_{2} \cdot \mathrm{SnO} .4 \mathrm{H}_{2} \mathrm{O}$.

${ }^{1}$ Compt. rend., 94, 792, 864 (1882); Ann. chim., [5] 27, I45 (1882). 